\title{
Brasília e seu território: a assimilação de princípios do planejamento inglês aos planos iniciais de cidades-satélites
}

\author{
Brasilia and its territory: assimilation of english \\ planning principles into the initial plans for satellite towns
}

Maria Fernanda Derntl [I]

\begin{abstract}
Resumo
A discussão sobre a apropriação de modelos e referências internacionais ao plano urbanístico de Brasília é um dos tópicos na historiografia sobre a capital e contribui para uma discussão mais ampla acerca de possíveis especificidades do movimento moderno no Brasil. No entanto, tal discussão tende a se restringir à concepção do núcleo traçado por Lúcio Costa em 1957. Este artigo pretende ir além da ênfase usual no Plano Piloto para analisar determinações iniciais para a organização do território do Distrito Federal e para a criação de suas cidades-satélites, entre fins da década de 1950 e início dos anos 1970. Essa análise aponta para a peculiar assimilação de um ideário inglês no campo do planejamento urbano e regional em circulação na primeira metade do século 20.
\end{abstract}

Palavras-chave: Brasília; cidades-satélites; Plano Piloto; planejamento urbano e regional; circulação de ideias.

\begin{abstract}
Appropriation of international models and principles by the urban plan of Brasilia is one of the topics within the historiography of the capital of Brazil and has contributed to a broader discussion about possible specificities of the modern movement in the country. However, this discussion has tended to be restricted to the design of the nucleus of the city outlined by Lucio Costa in 1957. The aim of this paper is to go beyond the customary emphasis on the Pilot Plan to analyze proposals for organizing the territory of the Federal District and creating satellite towns between the late 1950s and early 1960s. The analysis points out the peculiar assimilation of a set of English ideas and concepts that were in circulation in the field of urban and regional planning during the first half of the twentieth century.
\end{abstract}

Keywords: Brasília, satellite towns, Pilot Plan, urban and regional planning, circulation of ideas. 
Brasília, capital construída de acordo com os princípios modernistas da Carta de Atenas resultante do IV Congresso Internacional de Arquitetura Moderna, de 1933. Esse lugar-comum sobre a capital, embora pertinente, não considera um conjunto mais amplo de referências mobilizadas por propostas e determinações para a organização do território do Distrito Federal entre fins da década de 1950 e início dos anos 1960. Naquele período, iniciou-se uma política de assentamento de migrantes e populações pobres nas então denominadas cidades-satélites, situadas à distância do Plano Piloto e caracterizadas, de início, pelas habitações precárias e pela carência de serviços básicos de infraestrutura urbana. Este artigo busca contribuir para que tais núcleos-satélites - por vezes considerados secundários ou alheios à concepção da capital - sejam reconhecidos como parte intrínseca das formulações iniciais para o território de Brasília. A partir da retomada de um ideário em planejamento urbano e regional elaborado na Inglaterra desde fins do século 19, procura-se mostrar o específico modo de assimilação da noção de cidade-satélite ao contexto brasiliense.

A análise aqui proposta espera contribuir para elucidar um período crucial da urbanização de Brasília, com implicações na posterior definição da configuração metropolitana. Conforme apontou o geógrafo Aldo Paviani, em 1985, Brasília apresentava-se, então, como metrópole dispersa e polinucleada, dominada por um centro, o Plano Piloto, com diversos assentamentos periféricos dele dependentes, as cidades-satélites. Mais recentemente, a tese de doutorado de Brito (2009) acerca do processo de metropolização de Brasília urbana mostrou que um modelo da cidade central versus cidades-satélites, imposto desde fins da década de 1950, orientou os rumos do planejamento da capital de modo contundente até meados da década de 1970. E, em análise sobre os "genes" do plano de Brasília e os fatores que contribuíram para a atual configuração metropolitana, Ficher (2019) alertou para as profundas marcas deixadas por decisões tomadas à época da implantação da capital, especialmente no que diz respeito à preferência por assentamentos dispersos e baixas densidades. Tais autores despertaram o interesse por uma análise mais detida do modo como ideias e experiências em circulação internacional na primeira metade do século 20 foram mobilizadas por técnicos e arquitetos envolvidos com planos para estruturação territorial de Brasília e criação de suas primeiras cidades-satélites.

A ênfase tradicional dos estudos sobre a capital recaiu no Plano Piloto traçado por Lúcio Costa em 1957, enquanto as cidades-satélites - embora frequentemente lembradas pela crítica - permaneceram muitas vezes associadas ao "não planejado". Já nos anos 1970, estudos pioneiros de Evenson (1973) e Epstein (1973) mencionaram a existência de traçados urbanísticos oficiais para os núcleos-satélites. No entanto, ressalvou-se o caráter improvisado e pragmático de sua urbanização, em que "falar em 'plano' seria um exagero" (ibid., p. 68). O clássico trabalho de Yves Bruand sobre arquitetura moderna destacou Brasília como "apoteose do urbanismo brasileiro", mas considerou que os "planos pilotos das cidades-satélites" seriam "meros paliativos" na escala regional, necessários à garantia do caráter do Plano Piloto, mas sem representar "uma contribuição válida para o setor da criação de cidades novas" (Bruand, 2003, p. 364). A partir da década de 1980 , a análise da organização espacial das cidades-satélites 
teve impulso em estudos de viés morfológico conduzidos na FAU-UnB (Kohlsdorf, M. E., 1985, 1996; Turkienicz, 1987; Kohlsdorf, M. E.; Kohlsdorf, G.; Holanda, 2013). Observou-se a aplicação de um "modelo" e um tipo mórfico de "modernismo periférico", que reproduziria "traços problemáticos do modernismo clássico [do Plano Piloto], sem suas qualidades expressivas" (ibid.). 0 objetivo deste artigo é, mais do que analisar os planos urbanos em si mesmos, identificar o modo como vieram a contribuir para certo modo de conceber a ocupação do território do Distrito Federal.

A análise está baseada numa seleção de propostas desenvolvidas no contexto inglês de fins do século 19 e primeiras décadas do século 20 , nas quais cidades-satélites tiveram papel fundamental no sentido de impor esquemas de descentralização planejada à metrópole industrial. As definições de cidade-satélite estabelecidas nesse ideário mais amplo são cotejadas com formulações propostas para Brasília em meio a seu acelerado e conflituoso processo de urbanização desde fins dos anos 1950. Para isso, além de revisitar fontes já conhecidas, tais como escritos e depoimentos de protagonistas, o artigo também traz à luz uma documentação em boa parte inédita encontrada no Arquivo Público do Distrito Federal e no Arquivo Nacional do Rio de Janeiro, ao lado de planos urbanísticos depositados no acervo da atual Secretaria de Desenvolvimento Urbano e Habitação (Seduh). Ainda que não se conheça um registro abrangente capaz de esclarecer a postura adotada por autoridades na criação das cidades-satélites, foi possível encontrar indícios e evidências significativos a esse respeito em relatórios, atas de reuniões e determinações para implantar o sistema de abastecimento e a indústria na capital.
Neste artigo, procura-se ver as cidades-satélites de Brasília não tanto como deformação do Plano Piloto original ou distorção de modelos internacionais, mas, sobretudo, como específica assimilação, ao contexto da capital, de ideias e instrumentos no campo do planejamento urbano e regional. Essa perspectiva é tributária de estudos recentes acerca da circulação de ideias do urbanismo, nos quais se alerta que "transferências se dão, não raro, sob descompassos temporais e contextuais por parte dos receptores", cujo papel não é passivo, pois envolve operações de seleção e reformulação material e simbólica, com consequências por vezes imprevistas (Novick, 2010; Angotti-Salgueiro e Simões Jr, 2017).

\section{Paradigmas, referências e princípios}

A discussão acerca de referências internacionais subjacentes à concepção urbanística de Brasília é um dos tópicos na historiografia sobre a capital e, de modo mais amplo, contribui para o entendimento das especificidades que o movimento moderno viria a apresentar no Brasil. Conforme a análise de Ficher e Palazzo (2005), os "paradigmas urbanísticos" das propostas apresentados ao Concurso para a escoIha do plano da nova capital em 1956-57 compreenderam, desde conceitos e experiências elaborados na Europa no século 17, até um diversificado ideário moderno em voga nas décadas de 1950 e 1960. As cidades-satélites de Brasília evocam, ainda conforme os mesmos autores, as definições do arquiteto e urbanista alemão Ludwig Karl Hilberseimer acerca da criação de "bairros residenciais fechados em si 
mesmos", separados entre si e à distância da cidade central, além de estarem relacionadas com as noções de cidades-jardim, new towns e villes nouvelles (ibid.). As ideias de Ebenezer Howard para a cidade-jardim e seus desdobramentos posteriores no Plano de Londres e nas new towns foram parte do amplo leque de matrizes e referências urbanísticas de propostas que concorreram no Concurso do Plano Piloto da nova capital do Brasil em 1956-57 (Tavares, 2004).

Não apenas em planos para Brasília, mas também, conforme salientou Feldman (2009, 2014), numa prática profissional corrente no Brasil na década de 1950, o planejamento vinculou-se ao propósito do desenvolvimento e colocou em pauta a dimensão regional para abordar o problema da metrópole. As experiências brasileiras no campo do planejamento regional na década de 1950 envolveram distintas ênfases na descentralização urbana, mas apresentaram similar hierarquização da organização do território por meio de unidades de vizinhança, cidades-satélites e cinturões verdes. Nesse contexto de renovação das perspectivas de planejamento, o Plano de Londres e seus instrumentos urbanísticos, assim como os trabalhos da Tenessee Valley Authority (TVA), criada em 1933 nos EUA, tornaram-se importantes referências (Feldman, 2009).

Depoimentos, memórias e registros esparsos de protagonistas envolvidos com o Plano e a construção de Brasília trazem dados adicionais sobre possíveis paradigmas ou matrizes. Lúcio Costa, em um pequeno texto sobre os “'ingredientes' da concepção urbanística de Brasília", destacou elementos de suas memórias e vivências, que teriam sido integrados aos "velhos' princípios do Ciam": a "filiação intelectual francesa", a tradição "clássico-barroca" dos séculos 17, 18 e 19, os gramados ingleses, a "pureza" de Diamantina, fotografias da China no início do século 20 e, ainda, autoestradas e viadutos que conheceu nos arredores de Nova York (Costa, 2012). No entanto, esses "ingredientes" referem-se principalmente ao Plano Piloto e não esclarecem sobre a possível visão de Lúcio Costa a respeito do Distrito Federal (DF). Referências mais claras nesse sentido encontram-se em depoimentos de outros membros da equipe da Novacap (Companhia Urbanizadora da Nova Capital), empresa criada pelo presidente Juscelino Kubitschek em 1956, para conduzir o planejamento e a construção de Brasília. Pode-se destacar Jayme Zettel, que atuou como chefe do departamento de Urbanismo da Novacap nos anos iniciais de construção de Brasília e acompanhou a elaboração de planos para as primeiras cidades-satélites. Zettel citou, como referências teóricas para seu trabalho, o ideário da cidade-jardim, o Plano de Reconstrução de Londres (1944) de Patrick Abercrombie e as tabelas de dimensionamento de equipamentos urbanos, preconizadas por Giorgio Rigotti (Derntl, 2018). A referência a new towns inglesas foi também mencionada por Ernesto Silva, diretor, entre 1956 e 1961, da Novacap. Em depoimento de 1997, Silva fez uma crítica ao modo como as cidades-satélites desenvolveram-se depois dos anos 1960. No seu entender, Taguatinga não deveria ser considerada cidade-satélite, pois "não tem vida própria". Silva defendeu um modelo de cidade-satélite inspirado nas new towns construídas em Londres no pós-guerra, ou seja, "cidades independentes", "com 100 mil habitantes, 80 mil, 120 no máximo", nas quais "quem mora lá, trabalha lá" (Silva, 1997, p. 3).

0 contato de profissionais ligados à equipe da Novacap com experiências inglesas no 
campo do planejamento urbano e regional do pós-guerra foi propiciado, também, por viagens de formação e trabalho. 0 já mencionado Jayme Zettel esteve na Inglaterra, em 1959, estudando e trabalhando com o especialista em planejamento regional Percy Johnson-Marshall no London County Council (ou LCC, principal órgão da administração londrina, criado em 1889). Por sua vez, o arquiteto Gladson da Rocha, autor do plano urbanístico inicial da cidade-satélite do Gama (1965), viveu na capital inglesa por dois anos, entre 1965 e 1967, e, por indicação de William Holford, participou de projetos de new towns feitos pelo $\mathrm{Mi}$ nistério da Habitação e Governo Local. Cabe notar que William Holford - que viria a ser o presidente do júri do concurso do Plano Piloto realizado em 1956 e 1957 - envolveu-se ativamente com planos em escala regional para o pós-guerra inglês. Em suas funções no Ministério do Planejamento da Cidade e do Campo, Holford atuou na supervisão dos trabaIhos do Plano de Londres no início da década de 1940, ainda que discordasse em parte dos instrumentos de Abercrombie para promover a descentralização, especialmente quanto à diminuição do espaço para escritórios no núcleo central (Cherry e Penny, 1986). Já o arquiteto Harry Cole esteve na Inglaterra entre 1955 e 1958, quando fez parte do curso de pós-graduação, com ênfase em planejamento territorial, da University College London (LCC), e, em seguida, trabalhou no departamento de Arquitetura do LCC sob supervisão de Percy Johnson-Marshall (Lucchese, 2009). Conforme apontou Lucchese (ibid.), já em 1958 Cole se juntou à Novacap e, afinado com o pensamento inglês do pós-guerra, defendeu maior atenção ao planejamento da região no que diz respeito a cidades-satélites, transporte de massa e sistema viário; no entanto, essa postura teria causado desgastes com a equipe de arquitetos e especialmente com Lúcio Costa.

A referência a new towns como fonte de possíveis "experiências ou ensinamentos para Brasília" foi lembrada ainda em 1974, num contexto de discussão dos problemas urbanos e do planejamento da capital. Mas o arquiteto Ricardo Libanez Farret ressalvou então que, embora as new towns representassem uma contribuição válida "no plano físico", visaram a problemas distintos daqueles de Brasília, pois tiveram o sentido de promover a descentralização e o descongestionamento da atividade industrial ou reerguer zonas em decadência (Senado Federal, 1974, pp. 185-186).

Longe de pretender exaurir todo o possível conjunto de referências mobilizadas por determinações e planos para a estruturação do Distrito Federal, este artigo considera os dados provenientes da bibliografia e das declarações acima mencionadas para destacar, em seguida, algumas experiências voltadas para a reorganização da metrópole inglesa desde fins do século 19 até a primeira metade do século 20 .

\section{Cidades-jardim, cidades-satélites e new towns}

Conforme ressaltou Sica (1981), na crítica ao crescimento descontrolado de cidades industriais feita nas últimas décadas do século 19 por intelectuais alemães da linha conservadora-reformista, tais como Victor Aimé Huber e Julius Faucher, já se indicavam modelos alternativos de descentralização urbana por meio de núcleos-satélites semirrurais, devidamente 
dimensionados e equipados, separados entre si por grandes espaços verdes livres. É, no esquema de Ebenezer Howard para a cidade-jardim, porém, que, a partir da observação da realidade da metrópole industrial inglesa de fins do século 19, sintetizaram-se elementos de uma "tradição cultural" de enunciados e propostas de controle do crescimento urbano (ibid., p. 14). Os princípios da proposta de Howard foram a dispersão planejada; a limitação do tamanho da cidade; o acesso equilibrado a equipamentos, tais como parques e escolas; a relação urbano-rural; a organização da cidade em vizinhanças (wards no original); a propriedade fundiária em mãos de um truste que repassaria os ganhos com arrendamentos à municipalidade; e o empreendimento de caráter cooperativo (Osborn, 1969; Howard, 1902). Conforme ressaltou Hall (2011, p. 109) e como se depreende dos escritos de Howard (1902, p. 187), o modelo de "cidade social" só pode ser apreendido por completo considerando-se que envolvia não apenas a cidade-jardim central, mas também, uma vez que ela atingisse seu limite populacional, um conglomerado de cidades menores que iriam se formar ao seu redor, inclusive com sua própria administração. Essas cidades estariam separadas do núcleo principal por um cinturão verde" (belt of Green), numa "rede", unida por transporte rápido, que as ligaria entre si "em poucos minutos", configurando "uma única comunidade" (Figura1). Ainda que Howard não tenha empregado o termo "satélite", as cidades menores por ele previstas foram assim descritas por comentadores posteriores de sua obra, como, por exemplo, Gaskell (1981) e Carver (1962).

O emprego mais consequente da noção de "cidade-satélite" despontou num contexto não apenas de difusão como também de diluição do ideário inicial da cidade-jardim. No período entre guerras, emergiram na Europa e nos EUA, diversos estudos propositivos de novas formas de organização urbana, reunindo as ideias de cidade-jardim e descentralização planejada, nos quais se aventaram núcleos-satélites (Sica, 1981). Hall refere-se a cidades-satélites propostas ou construídas nas primeiras décadas do século 20 por iniciativa de R. Unwin em Londres, Ernst May em Frankfurt, Barry Parker em Manchester e do LCC em Essex, como "apostasia", "concessão" e "antítese" da cidade-jardim, pois, ainda que inspiradas em seu ideário, não viriam a produzir núcleos de caráter independentes, mas sim subúrbios-jardim semiautônomos e dependentes de um centro (Hall, 2011, p. 82, pp. 124-125, pp. 137-138).

Algumas das mais significativas propostas do período entre guerras para criação de cidades-satélites vieram de homens envolvidos com a criação e difusão das cidades-jardim, tais como Raymond Unwin - que, em 1903, havia se associado a Barry Parker para o empreendimento da cidade-jardim de Letchworth - e Charles Benjamin Purdom, que participou da fundação de Letchworth e Welwyn. Em 1920, numa Conferência promovida pela Associação Garden Cities, Purdom apresentou um plano (no ano seguinte reproduzido no livro Town Theory and Practice) para a realização de vinte e três cidades-satélites (satelitte-towns) em torno de Londres, incluindo as iniciativas de Welwyn e Letchworth. Por sua vez, Raymon Unwin viria a ter papel fundamental no sentido de adaptar as ideias de Howard ao intuito de viabilizar o controle da densidade e da população da metrópole londrina. Desde 1919, Unwin foi funcionário do Ministério da Saúde - órgão então responsável por questões de planejamento-e, depois, 
consultor técnico do Comitê de Planejamento Regional para a Grande Londres criado em 1927. Nesse encargo, Unwin contribuiu decisivamente para o relatório final, publicado em 1933, no qual se delineia um plano regional envolvendo um sistema de parkways, a criação de uma cinta verde (Green girdle) em volta de Londres e um padrão de crescimento por meio de subúrbios planejados, cidades-satélites e cidades-jardim industriais. As propostas de Purdom (Figura 2) e Unwin (Figura 3) expandiram a ideia de descentralização da metrópole, com base no ideário de cidade-jardim, em planos em escala regional (Beloto, 2015; Hall, 2011; Sica, 1981). Mas, também implicaram significativa inflexão a princípios da cidade-jardim ao propor núcleos-satélites mais dependentes do núcleo central do que havia previsto Howard e, considerando a necessidade de lidar com os problemas da cidade existente, ao atribuir papel fundamental ao Estado em sua realização. Conforme salientou Hardy (1991), um marco fundamental na campanha promovida pela Associação Garden Cities foi mesmo a mudança da preocupação original com cidades-jardim promovidas pela iniciativa privada para a defesa da atuação do Estado no sentido de torná-las parte de uma política nacional no primeiro pós-guerra, o que incluiria a expansão controlada de cidades existentes por meio de cidades-jardim satélites.

No entanto, líderes do movimento em prol da difusão das cidades-jardim fizeram questão de ressaltar que a noção de cidade-satélite não implicaria uma inflexão a seus princípios originais. Em seus escritos, tanto Osborn (1969) como Purdom (1949) rechaçaram a associação entre cidade-satélite e subúrbio industrial situado no campo ou subúrbio-jardim. Ambos propuseram o emprego do termo "cidade-satélite" como modo de recuperar a intenção original do termo cidade-jardim, mas considerando que tais núcleos apresentariam "um vínculo econômico especial" com Londres (Osborn, 1969, p. 182), ou seriam "dependentes em alguns aspectos de outra cidade" (Purdom, 1949, pp. 22-23), o que consideravam inevitável em novas cidades então construídas. Na definição de Purdom, a cidade-satélite seria "um organismo sob influência de outro mais poderoso, mas com sua própria identidade", além de uma "uma unidade cívica distinta, com seu próprio governo local e vida corporativa", de modo que "a ênfase estaria, portanto, mais na ideia de 'cidade' [town] do que na de satélite" (ibid., pp. 23-24).

É uma similar noção de cidade-satélite de caráter tendencialmente autônomo que se faz presente no Plano de Londres (Greater London Plan) apresentado por Patrick Abercrombie ao Ministério de Planejamento da Cidade e do Campo em 1944 e aprovado em 1946, no contexto de reconstrução pós-guerra. Embora derive de uma sequência de formulações que remetem em última análise a Ebenezer Howard, o Plano de Londres sintetiza soluções urbanísticas experimentadas antes de modo isolado e só então empregadas num empenho coordenado (Sica, 1981). A preocupação fundamental era controlar o crescimento metropolitano por meio da descentralização, com base no deslocamento de indústrias e na transferência de pouco mais de um milhão de pessoas. O Plano visava a dar configuração mais clara e ordenada para o que reconhecia ser uma tendência já existente de estruturação urbana. Propôs-se uma sequência de quatro anéis com densidades decrescentes do centro aos subúrbios: o primeiro anel (inner urban ring) compreenderia a área construída do LCC, 
incluindo áreas a serem descentralizadas; o segundo anel (suburban ring), é uma zona que deveria ser mantida "estática" quanto a população e indústria; o terceiro anel (Green belt ring) deveria abrigar áreas verdes livres para funções recreativas e, em menor escala, para agricultura, limitando-se o crescimento de comunidades ali existentes; por fim, haveria um anel externo ou rural (outer country ring), no qual seria permitida a expansão controlada de núcleos existentes e deveriam ser construídas cidades-satélites, de modo a receber a população descentralizada, em meio a espaços livres com predomínio da agricultura. Cada um desses anéis seria, por sua vez, definido por um anel viário, e os espaços livres teriam função estruturadora como fundo verde para os núcleos de urbanização (Abercrombie, 1945).

Figura 1 - Diagrama da cidade social proposta por E. Howard

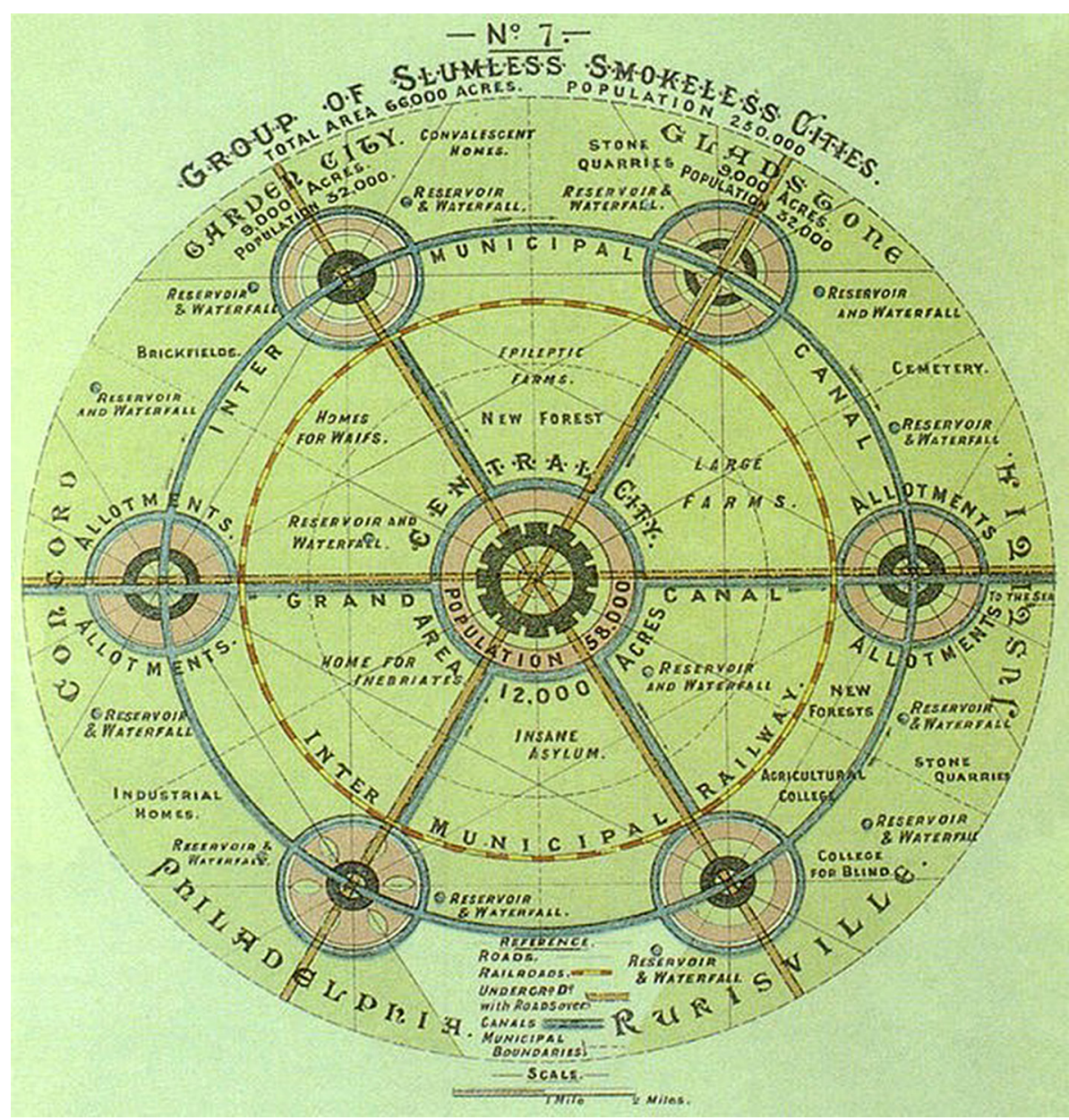

Fonte: Howard, E (1902). 
Figura 2 - Charles B. Purdom. Cidades-satélites em torno de Londres: um diagrama mostrando como poderiam ser

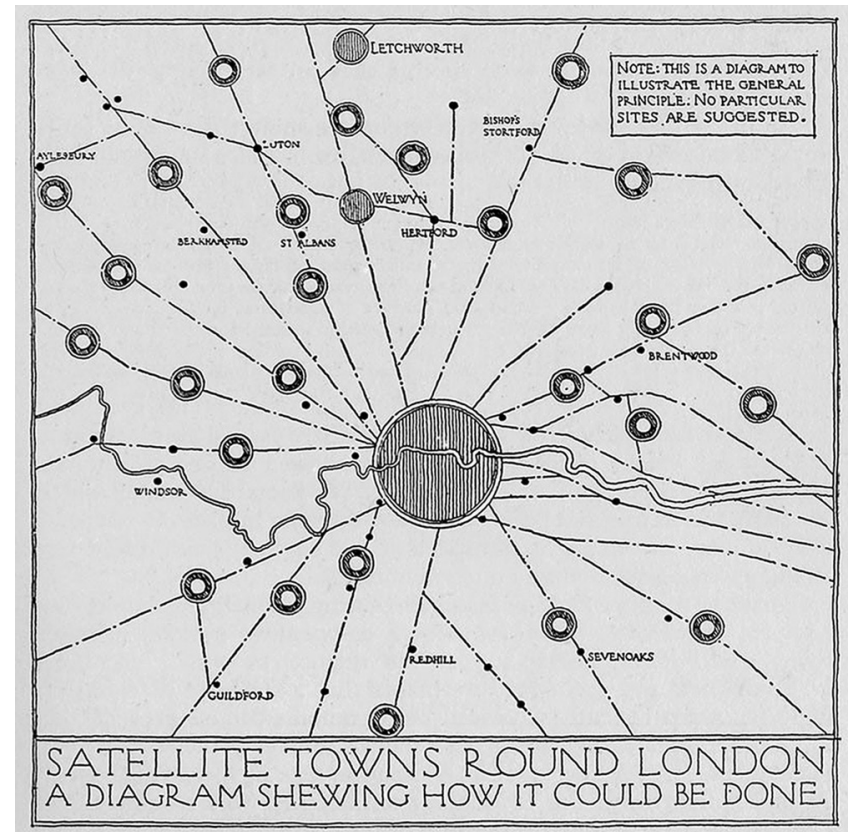

Fonte: Lethaby et al. (1921).

Figura 3 - A cinta verde de Raymond Unwin, 1933

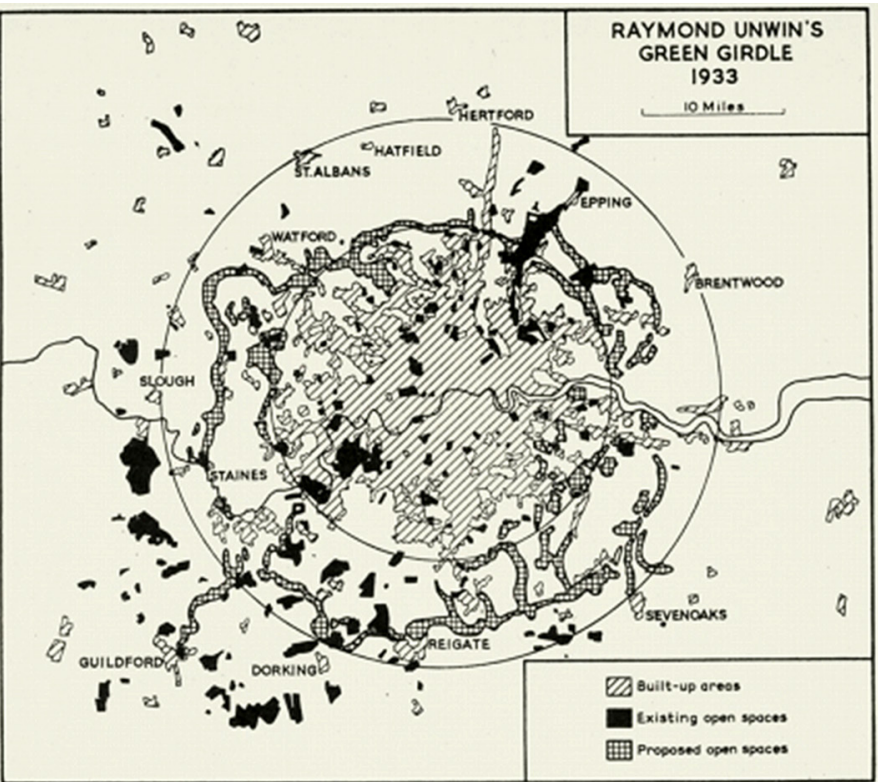

Fonte: Thomas(1964). 
Figura 4 - Proposta de ampliação de áreas construídas existentes e locais para novas cidades-satélites

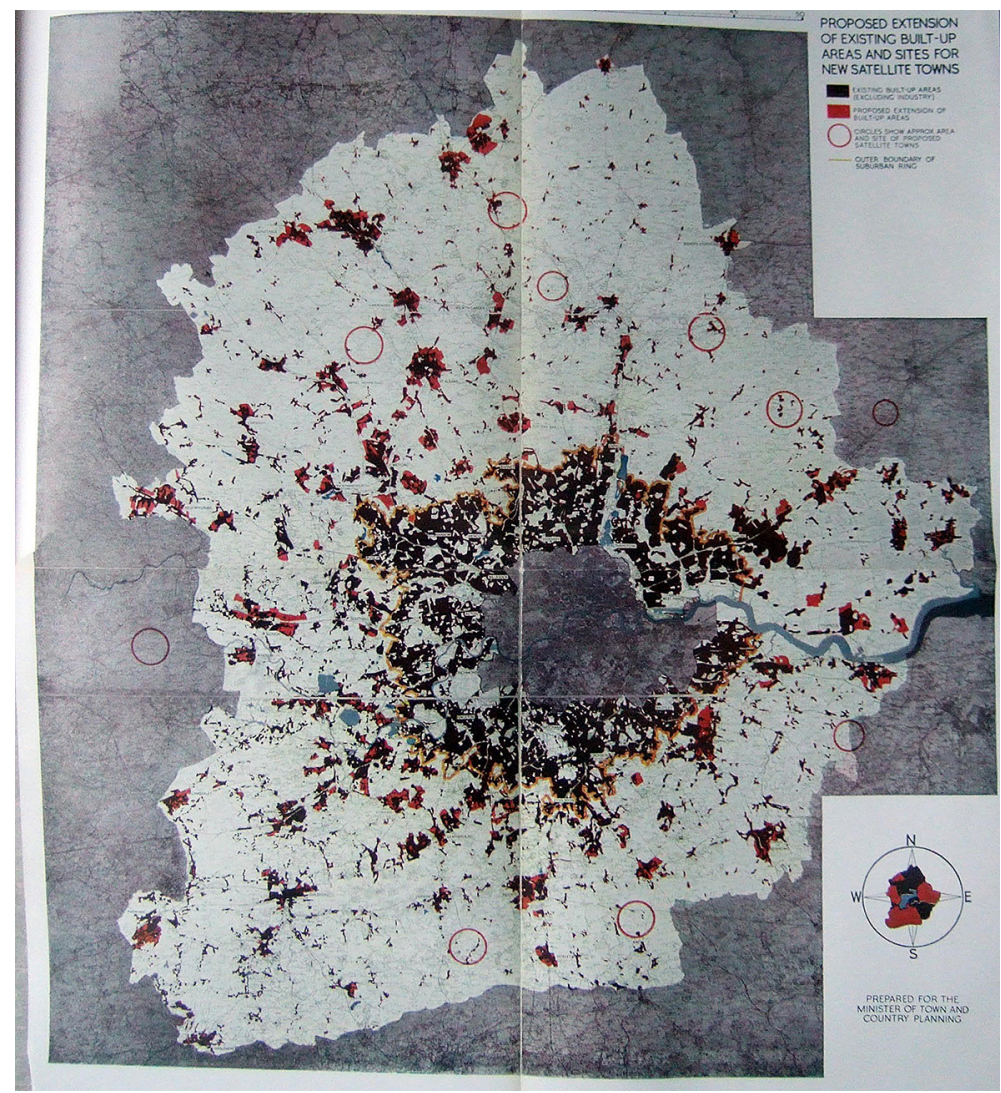

Fonte: Abercrombie (1945).

Abercrombie propôs a criação de oito cidades-satélites, também chamadas, no Plano, de new towns ou new satellite towns, a cerca de 32 a $56 \mathrm{~km}$ de Londres, situadas no anel mais externo então definido e fora do cinturão verde. Elas seriam um dos quatro tipos básicos de comunidade previstas, ao lado dos bairros (boroughs) antigos do centro, dos subúrbios e das cidades existentes. 0 plano indica dez sítios onde poderiam ser erguidas tais cidades-satélites e apresenta um estudo de uma delas. As novas cidades do Plano de Londres aproximam-se das definições de cidade-satélite já mencionadas, propostas por Unwin, Osborn e Purdom, inclusive quanto a terem alguma unidade de governo local. Mas, considera-se ainda que a população das new towns deveria ser o dobro daquela recomendada antes por Howard para as cidades menores em seu esquema: cada uma delas teria população máxima de 60.000 habitantes e contaria com uma variedade de opções de emprego, 
de forma a garantir a estabilidade de sua população. No Plano de Londres, as new towns poderiam receber indústrias e deveriam estar organizadas em unidades de vizinhança (cada uma tendo 1.200 a 3.000 casas), de modo a ter "vida e caráter próprios", mas em harmonia com a região (Abercrombie, 1945, p. 113). As new towns deveriam manter vínculo com Londres, onde se encontrariam as atividades culturais e de diversão mais importantes, mas não deveriam ser cidades-dormitório nem levar a movimentos pendulares. Comunidades "quase satélites" (quasi-satellites) - ou seja, núcleos residenciais próximos a cidades onde haveria locais de trabalho - foram admitidas no Plano apenas como política a curto prazo para atender a necessidades imediatas de provisão de moradia no pós-guerra, devendo vir a se integrar aos núcleos vizinhos para constituir satélites plenos.

Já, em 1946, constituiu-se um Comitê de Novas Cidades para abordar a questão das cidades-satélites no quadro de objetivos nacionais de descentralização planejada e, em agosto do mesmo ano, promulgou-se o New Towns Act, que deu início à criação dos novos núcleos na Inglaterra, a começar por Stevenage, contando-se, até o início dos anos 1970, vinte e um deles (Hall et al., 1973). Em meados dos anos 1970, porém, a intervenção em centros urbanos e não mais a criação de new towns se tornou a orientação principal das políticas urbanas inglesas. Cabe notar que a denominação new town, embora empregada inicialmente de modo intercambiável com a de satellite town, acabou prevalecendo sobre esta última. A definição de um conceito preciso de new town permanece controversa na vasta bibliografia a seu respeito e, conforme observaram Peter Hall et al. (1973), seus objetivos, origens e situações geográficas são muito distintos; mesmo assim, duas ideias podem ser consideradas dominantes em sua concepção: a de serem contidas em termos de incluir trabaIho, serviços e comércio para as necessidades diárias e a de equilíbrio entre diferentes grupos socioeconômicos ali presentes.

Essa breve retomada de algumas propostas seminais na história do urbanismo envolvendo cidades-satélites não pretendeu estabelecer uma definição unívoca sobre elas. Propostas de cidades-satélites bem distintas daquelas analisadas aqui foram aventadas, por exemplo, pelo já citado Hilberseimer, que em 1923 defendeu bairros residenciais dependentes dos lugares de trabalho situados no núcleo central, mas, em 1927, criticou as implicações desvantajosas desse sistema para a organização do tráfego do centro urbano da metrópole (Hilberseimer, 2012). Além disso, observou-se uma similar concepção de cidade-satélite nas propostas de Unwin, Purdom e no Plano de Londres. Como parte de esquemas de descentralização metropolitana, as cidades-satélites por eles concebidas estariam em relação com o centro, mas deviam ter certa autonomia e associaram-se a outros dispositivos de planejamento regional tais como cinturões verdes, unidades de vizinhança e vias expressas. Ressalta-se aqui que a segregação de grupos sociais foi expressamente condenada, ainda que tenha vindo caracterizar muitas das iniciativas dessa natureza. Em 1901, Parker e Unwin já recomendavam "evitar a separação total das diferentes classes de pessoas" (apud Hall, 2011, p. 117), e, no Plano de Londres, alertou-se para problemas sociais e administrativos causados pela segregação por grupos de renda ou faixa etária, assim como pela instabilidade da população (Abercrombie, 1945). Em Brasília, 
já no início da atuação da Novacap, surgiram propostas de criação de cidades-satélites com conotações específicas, como se verá a seguir.

\section{Planos e definições para as cidades-satélites de Brasília: apropriações}

O plano vencedor de Lúcio Costa para a capital não compreendeu, como se sabe, sua expansão no DF, pois, conforme conhecido trecho do seu Relatório, partiu do princípio de que a cidade "não será, no caso, decorrência do planejamento regional, mas a causa dele: sua fundação é que dará ensejo ao ulterior desenvolvimento planejado da região" (Costa, 1991[1957], p. 20). Adotou-se o pressuposto de que a cidade de tamanho limitado e traçado ordenado seria o marco inicial de uma ocupação planejada de seu território, podendo-se entender que estava implícito o crescimento por meio de cidades-satélites também ordenadas. Conforme declarou Lúcio Costa no início dos anos 1970:

o Plano estabelecido era para que Brasília se mantivesse dentro dos limites para os quais foi planejada, de 500 a 700 mil habitantes. Ao aproximar-se desses limites, então, é que seriam planejadas as Cidades-Satélites, para que estas se expandissem ordenadamente, racionalmente projetadas, arquitetonicamente definidas. Este era o Plano proposto. (Costa, 1974a, p. 26)

Na mesma ocasião, Lucio Costa defendeu a criação de "dois anéis em volta do núcleo piloto": o primeiro deles seria um "cinturão interno" destinado a atividades agrícolas e granjas e, depreende-se do texto, onde haveria cidades-satélites separadas entre si; o segundo anel seria reservado para atividades industriais, de modo que as populações dos núcleos satélites, "em vez de ficarem em função do centro, da matriz, seriam afastadas para a periferia, por uma força centrífuga" e viveriam em função de atividades industriais ou rurais (ibid.). Ainda no mesmo ano, Lucio Costa condenou a existência de "pseudocidades-satélites" na capital e reafirmou a orientação para que atividades industriais se instalassem "além das áreas urbanas satélites, conquanto próximas", a fim de aproveitar a mão de obra ali existente e evitar a "exclusiva dependência metropolitana" (Costa, 1974b, p. 279). Mais tarde, Lucio Costa declarou, na mesma linha, que a intenção do "engenheiro, Sr. Pinheiro" provavelmente se referindo a Israel Pinheiro, presidente da Novacap - fora a seguinte:

uma vez terminada a fase inicial, dos 3 anos iniciais de trabalho intensivo, um terço da população obreira que tinha ido a Brasília para construir a cidade, chegado o momento da inauguração, voltaria para o seu "país" de origem; outro terço seria absorvido pelas próprias atividades locais urbanas; para o terceiro terço - como eram quase todos operários de tradição rural - a solução seria criar um cinturão verde, agrícola, em torno da cidade. (Costa apud Oliveira, 2005)

A organização do território por meio de anéis concêntricos - um deles configurando um cinturão verde - e a noção de cidades-satélites de caráter relativamente independente foram também, como se viu, princípios de um ideário inglês de planejamento da descentralização metropolitana. 
Numa similar orientação, William Holford, presidente do júri do Concurso $\mathrm{Na}$ cional que elegeu a proposta de Lucio Costa, deixou indicações a respeito do modo como concebia cidades-satélites. Uma das "vantagens" do Plano Piloto de Lucio Costa seria propiciar o crescimento urbano, após 20 anos de sua construção, nas penínsulas do lago e por meio de cidades-satélites (Holford et al., 1991, p. 35). Dois dias depois da divulgação do resultado do concurso, em carta de 18 de março de 1957 ao diretor da Novacap, Israel Pinheiro, Holford esclareceu que, no seu entender, "centros agrícolas e industriais" deveriam ser planejados, a fim de atuar "como cidades-satélites e de apoio dentro da região". Uma cidade-satélite deveria ter como características essenciais ser "autossuficiente para fins ordinários de vida, trabalho e recreação" e estar ligada "por rápidas rodovias e ferrovias com a cidade-mãe, para as funções especiais que somente uma grande cidade pode oferecer, como universidade, teatro de ópera, comemorações e cerimônias públicas, departamentos governamentais, etc." (Holford, 2012 [1957], p. 32). Lucio Costa e William Holford parecem de acordo ao atribuir um caráter relativamente autônomo a cidades-satélites, já que ambos aludem a vínculos de ligação com o centro, mas recomendam evitar a criação de subúrbios dele dependentes.

Nos registros de decisões tomadas pela Novacap, referências a cidades-satélites foram encontradas desde 1957 - portanto antes da data usualmente adotada pela bibliografia corrente, que toma como marco inicial a implantação de Taguatinga em 1958. O Conselho da Companhia determinou, em 1957, que "os estabelecimentos industriais do novo Distrito Federal serão localizados nas 'cidades satélites' da Nova Capital" e só "por exceção" na zona rural, mediante condições então estabelecidas para o tamanho dos lotes, os prazos de seu arrendamento e o tipo de indústria (Ata da reunião do Conselho apud brasília, 1957, p. 23). A decisão deu-se em meio a outras definições sobre o modo de estruturar o território do Distrito Federal, envolvendo, além da localização das indústrias, a formação de um cinturão verde em torno do Plano Piloto, onde haveria chácaras, sítios e granjas.

Essas referências sobre a organização e distribuição de atividades no DF remetem a instrumentos de planejamento regional em voga nos anos 1950 - baseados na relação entre cidade central e cidades-satélites, mediada por grandes espaços livres -, mas exprimem também uma preocupação específica no sentido de garantir a produção agrícola e o abastecimento de gêneros alimentícios. Depois da criação, ainda pelo presidente Café Filho, do Conselho Coordenador de Abastecimento (CCA), em 2 de dezembro de 1954 (extinto em 1962), foi elaborado um plano nacional com o objetivo básico de regularizar o abastecimento de alimentos aos grandes centros consumidores. Numa similar orientação, em 1957 o presidente Juscelino Kubitschek determinou a elaboração de programas específicos, a partir do levantamento das condições de produção em cada uma das regiões do País, prevendo a construção de centros de abastecimento nas capitais estaduais e no Distrito Federal.

O jornalista e economista Benjamim Soares Cabello, que havia atuado em órgãos ligados ao abastecimento nacional desde os anos 1940, assinou o Plano de Abastecimento de Brasília, datado de novembro de 1957, e também o Plano Industrial para Brasília, dirigido a Novacap e datado de dezembro do 
mesmo ano, ambos com referências à ideia de construir cidades-satélites. O Plano de Abastecimento almejava "dotar a capital de um perfeito sistema de abastecimento a sua população" e promover o desenvolvimento econômico e social. Nesse Plano, reafirma-se a intenção de que cidades-satélites só deveriam ser construídas depois que a população do Plano Piloto atingisse, "em futuro não remoto", a cifra de 500 mil habitantes, e estima-se que em 10 anos já haveria dois milhões de pessoas vivendo na capital. ${ }^{1}$ O Plano baseava-se na articulação entre mercados do agricultor, centro de abastecimento e supermercados. 0 centro de abastecimento deveria estar situado nas proximidades do Plano Piloto, conforme indicado no Relatório apresentado por Lucio Costa em 1957, e foi concebido como "uma cidade à parte", contendo setores dedicados a estocagem, beneficiamento, comércio, administração e serviços gerais. 0 centro de abastecimento de Brasília deveria servir não apenas para a população do Plano Piloto, mas também das futuras cidades-satélites, nas quais haveria apenas mercados públicos locais. Apesar de se ter considerado que cidades-satélites deveriam ser construídas "em futuro não remoto", abriu-se exceção para propor a criação imediata de um núcleo dessa natureza, descrito como "vila residencial" e situado ao lado do centro de abastecimento, tendo casas para funcionários municipais, federais e da Novacap, incluindo "diferentes categoriais sociais". Essa vila residencial estaria ligada a uma "cidade industrial" a ser instalada também nas proximidades do centro de abastecimento.

Tal proposta foi retomada no Plano Industrial elaborado por Benjamim Soares Cabello em 1957. Ali se considerou a anterior determinação da Novacap para que indústrias só pudessem se instalar em cidades-satélites (ou seja, não no Plano Piloto nem na área rural), mas alertou-se que isso exigiria imediata elaboração de planos para aqueles núcleos ou, pelo menos, a definição de sua localização. Propôs-se então, em vez disso, a concentração de indústrias em um ponto adequado, de modo a não comprometer nem a "harmonia urbanística" do Plano Piloto, nem a "urbanização das futuras cidades-satélites". A indicação de erguer um centro industrial numa cidade-satélite à distância do Plano Piloto - idealmente a $30 \mathrm{~km}$ dele - e nas proximidades do centro de abastecimento estaria em sintonia com as preocupações expressas depois por Lúcio Costa e pode ser relacionada também com as determinações do Plano da Grande Londres para descentralização industrial. No entanto, no Plano da Grande Londres, embora tanto cidades existentes quanto novos satélites tenham sido considerados adequados para abrigar a indústria descentralizada, recomendou-se, diferentemente da proposta para Brasília, manter a autonomia dos núcleos e evitar o predomínio de uma função. Ainda que as recomendações de Benjamim Cabello não tenham se efetivado de imediato e em seus exatos termos, no início dos anos 1960, construiu-se o Setor Residencial Indústria e Abastecimento, expandido em 1967, para formar uma das cidades-satélites de Brasília, denominada Guará.

No ano seguinte àqueles planos para Brasília, o arquiteto Lucídio Guimarães Albuquerque, chefe da Comissão de Projetos e Obras do CCA, afirmou ter concluído seu próprio trabalho no Plano de Abastecimento e enviou cópia dele para o presidente da República, Lúcio Costa e Benjamim Soares Cabello. Com base nos princípios do Plano de Abastecimento antes citado, Lucídio Albuquerque 
desenvolveu, para a Novacap, um estudo de um modelo de ocupação do território rural do DF baseado na ideia de agrovilas ou, na denominação mais usada por ele, Unidades Socioeconômicas Rurais (Users) (Albuquerque, 1960). O propósito das Users era dar apoio ao desenvolvimento de comunidades rurais na área de sua influência e articular um sistema cooperativista de produção. Em cada uma delas haveria órgãos de administração rural, posto de correio, estabelecimentos de assistência médico-hospitalar, posto policial, escola primária, parques, centros de cultura, lazer e recreação, igrejas e um núcleo residencial. Já em 1962, porém, decidiu-se abandonar a ideia de implantação das Users, passando-se a enfatizar núcleos rurais com caráter autônomo (Rabelo Jr, 1992).
Os planos de Users para Brasília permitem aproximações com planos para agrovilas previstas em iniciativas de planejamento regional promovidas no Norte do Paraná na primeira metade do século 20 e, posteriormente, ao longo da Transamazônica na década de 1970. A partir dos princípios de um "urbanismo rural", as agrovilas previstas nessas regiões seriam pequenos centros urbanos para moradia e integração social de trabalhadores rurais, contendo um programa de equipamentos coletivos similar àquele previsto nas Users de Brasília. Essas agrovilas não se relacionam propriamente com o conceito de cidade-satélite, mas remetem a uma matriz urbanística compartilhada, pois implicavam "uma ampliação (conceitual e geográfica) da teoria howardiana" de cidades-jardim (Rego, 2015).

Figura 5 - Departamento de Terras e Agricultura.

"Rede de instituições do sistema de Abastecimento de Brasília", ca. 1959

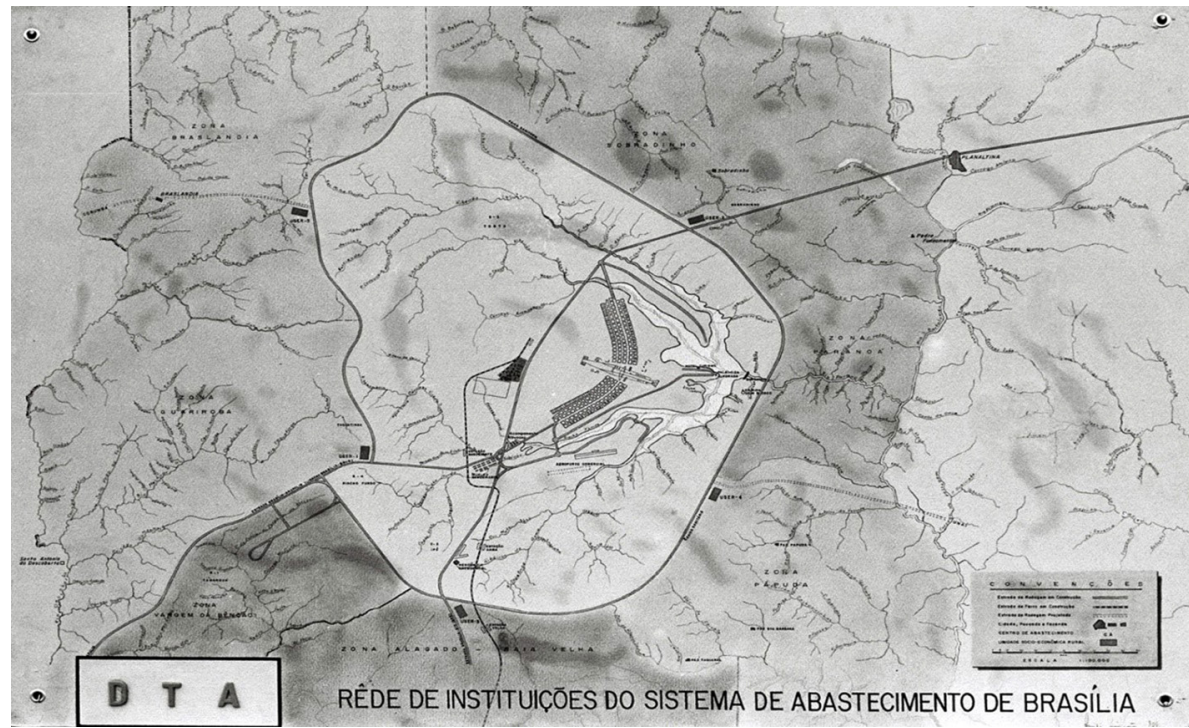

Fonte: ArPDF 
Um mapa da "rede de instituições do sistema de abastecimento de Brasília", possivelmente feito por volta de 1959, mostra a disposição proposta para as Users no DF e a localização do centro de abastecimento, tendo como baliza as principais estradas. É evidente a função estruturadora de um cinturão central, na linha do que vinham propondo as experiências inglesas antes analisadas. No entanto, esse anel que envolve o Plano Piloto e seu entorno imediato denomina-se "faixa sanitária", expressão que viria a predominar em relação a "cinturão verde". No já mencionado Plano de Abastecimento de Brasília elaborado por Benjamim Cabello em 1957, houve menção a essa "faixa sanitária" quando se propôs dividir a zona rural do DF em sete regiões agrícolas, "excluída da zona rural a área circunscrita pela faixa de proteção às vertentes (faixa sanitária)". Em 1958, a faixa sanitária foi aprovada pela Novacap, com o propósito de restringir a ocupação na área correspondente à bacia hidrográfica do lago Paranoá, formando uma "parte não urbanizada [que] somente poderá ser utilizada pela Novacap, ou para qualquer outra finalidade mediante autorização expressa do Conselho" (Ata da reunião do Conselho da Novacap, apud brasília, 1958, pp. 23-24). Desse modo, pretendia-se manter o traçado do Plano Piloto contido, bem-definido e isolado de seu entorno, de acordo com o "princípio constitucional", definido por Lúcio Costa, de "não prolongamento suburbano" ao longo das vias que conduzem a núcleos satélites (Costa, 1974a). A definição da faixa sanitária de Brasília foi, portanto, mais restritiva do que aquela do cinturão verde londrino de 1944 , em que se permitia uso controlado para lazer e atividades agrícolas.
Os planos e decisões iniciais da Novacap e seus colaboradores permitem ver uma peculiar transposição do ideário internacional em planejamento urbano e regional para o contexto muito distinto de implantação da nova capital em terras de escassa ocupação no interior do Brasil. Elementos fundamentais dos esquemas de descentralização planejada estão de algum modo ali presentes - a cidade central, as cidades-satélites e o cinturão verde -, mas, além de ter configuração e propósitos específicos, compuseram um conjunto de iniciativas e decisões que, embora tendam a mostrar coerência entre si, não chegaram a ser dispostas num plano único e coordenado para definir a ocupação do DF. Durante os anos iniciais de construção de Brasília, o desenvolvimento das obras e as demandas ali surgidas exigiram outras redefinições no modo de estruturar o território da capital, conforme abordaremos em seguida.

\section{A redefinição das cidades- -satélites durante a construção}

Conforme salientou Holston (1993), as demandas e manifestações de migrantes recém-chegados a Brasília pela posse de terras e pelo acesso a serviços de infraestrutura urbana básica foram determinantes para que a Novacap iniciasse a construção de cidades-satélites. Os primeiros casos de tais manifestações foram, a partir de 1958, a ocupação das terras junto ao Núcleo Bandeirante, então denominadas Vila Sarah Kubitschek; a formação de uma associação de moradores na vila Amaury, que deveria ser desativada e inundada após a construção do lago Paranoá; e a campanha de moradores 
da Cidade Livre para que aquele núcleo provisório de comércio e serviços junto à sede da Novacap fosse mantido depois da inauguração de Brasília. Esses movimentos levaram a Novacap a criar núcleos à distância do Plano Piloto onde os migrantes receberam lotes de terra para habitar, dando origem às respectivas cidades-satélites de Taguatinga, Sobradinho e Núcleo Bandeirante.

De início, parece ter havido a preocupação de manter a ideia antes aventada de localizar indústrias em cidades-satélites. Já em 1958, previram-se em Taguatinga 15 hectares para "pequenas indústrias, artesanatos e atividades auxiliares" e, no ano seguinte, indústrias de fundição de laminação foram destinadas não só a Taguatinga como também a Sobradinho (Ata da Diretoria, 18 nov 1959, apud brasília, n. 19, p. 23). Em novembro de 1959, a Companhia aprovou as "plantas do loteamento" das cidades-satélites de Sobradinho e Taguatinga e, no ano seguinte, há referência ao Gama e Paranoá, esta última não implantada (brasilia, 1960, p. 18).

Os mais antigos planos urbanísticos de cidades-satélites que conhecemos datam de 1959 e início dos anos 1960 e foram elaborados por arquitetos da Divisão de Arquitetura e Urbanismo da Novacap, como, por exemplo, as plantas de um setor de Taguatinga e do Núcleo Bandeirante (Figuras 6 e 7). No entanto, há registro de que, em maio de 1961, a Novacap decidiu aceitar uma proposta da Pontifícia Universidade do Rio de Janeiro para planejamento das cidades-satélites, "tendo em vista a urgente necessidade dos planos relativos àqueles núcleos e à inexistência, nos quadros da companhia, de órgão especializado

Figura 6 - Codeplan. Cidade satélite de Taguatinga, setor $\mathrm{H}$ - Norte.

Projeto de loteamento e arruamento, 1985. Cópia de original de 3 de abril de 1962

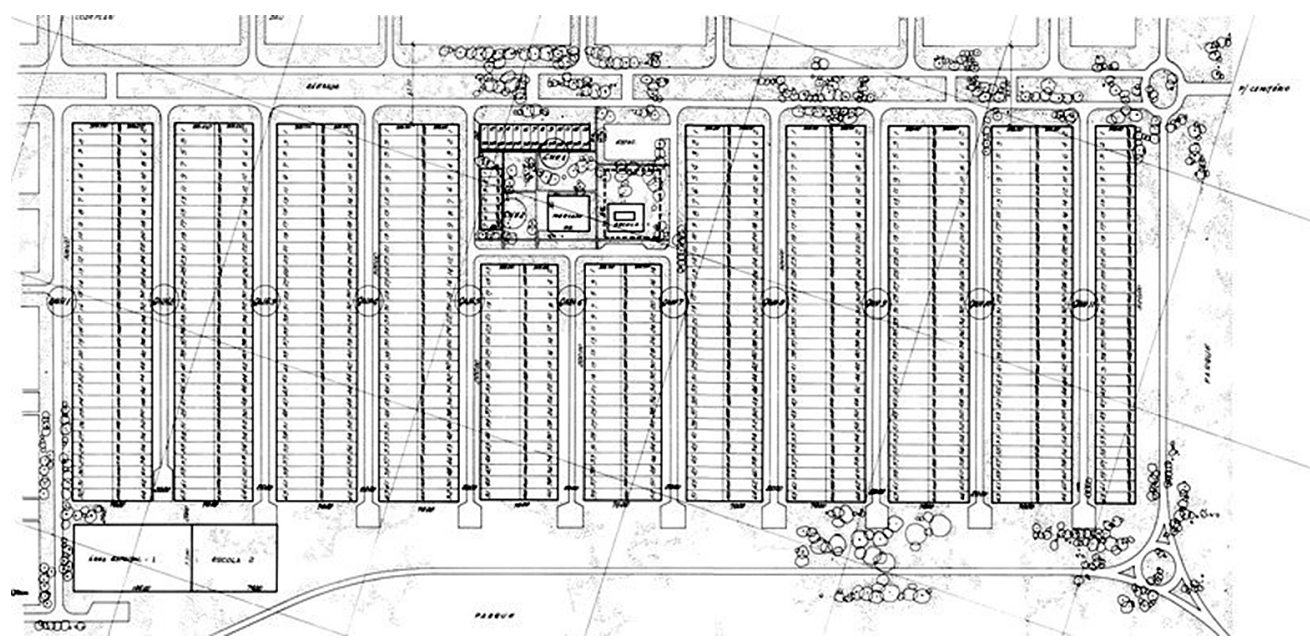

Fonte: Acervo da Seduh. 
Figura 7 - Divisão de Arquitetura e Urbanismo - GDF. Núcleo Bandeirante, planta geral,1965

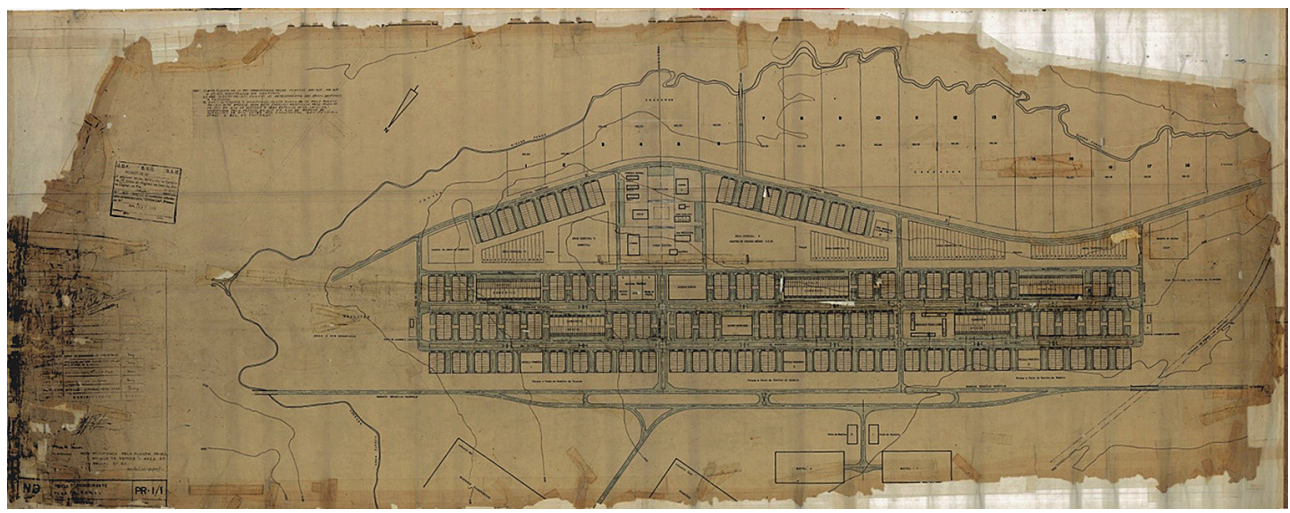

Fonte: Acervo da Seduh.

Figura 8 - Conselho Nacional de Geografia, Divisão de Cartografia. "Distrito Federal". Mapa elaborado em 1960 e atualizado em 1963

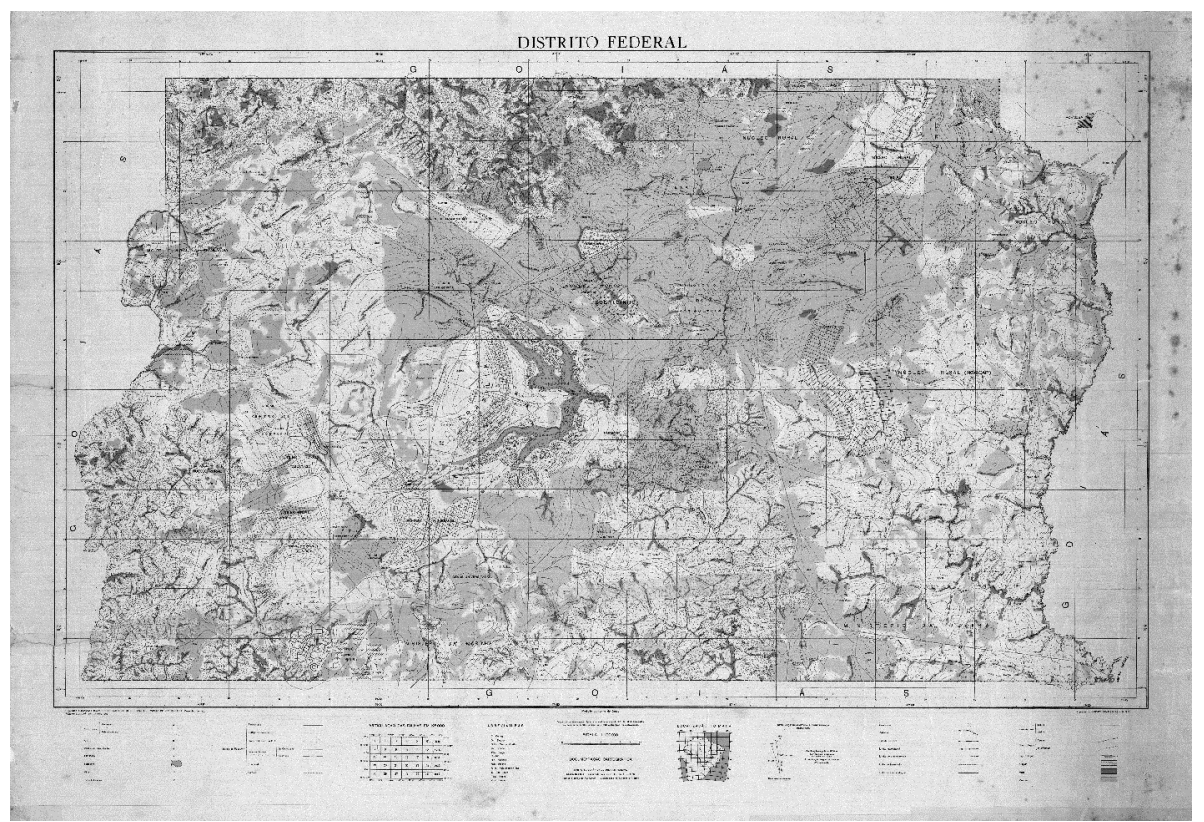

Fonte: ArPDF. 
que se incumba da tarefa" (Ata da Diretoria da Novacap, 23 de maio de 1961). Ao que parece, tal proposta não foi levada a efeito, pois os planos continuaram a ser realizados por profissionais da Novacap ou, a partir de 1964, pela Codeplan. De todo modo, essa decisão é sugestiva de que uma política de elaboração e expansão de cidades-satélites tinha sido assumida pela Companhia.

Um mapa de 1963 trazendo "projetos e obras da Novacap" mostra o Plano Piloto e as quadras junto ao lago Paranoá separados - por estradas-parque e pela faixa sanitária - de um território circundante onde se veem as cidades-satélites de Taguatinga, Gama, Sobradinho, Núcleo Bandeirante e Planaltina, em meio a grandes lotes de parcelamentos rurais e sedes de granjas-modelo (Figura 8). Apesar da proximidade do Núcleo Bandeirante ao Plano Piloto, o mapa ainda permite ver o paradigma da cidade central separada das cidades-satélites por espaços verdes, o que dificilmente se sustentaria nos anos seguintes, quando a expansão de Brasília tendeu a se tornar mais contínua, embora ainda fragmentada e policêntrica.

Ainda que o modo inicial de distribuição das cidades-satélites no território tenha se apoiado nesse princípio fundamental da descentralização planejada, cedo também se definiu uma peculiar configuração de cidade-satélite. Do ponto de vista dos grupos sociais ali alocados, houve controle por parte da Novacap para que apenas "trabalhadores e servidores modestos" pudessem adquirir lotes em cidades-satélites, e os lotes comerciais fossem distribuídos a "comerciantes de poucos recursos" (Silva, 1970, p. 316). Ao lado disso, 0 acesso à moradia no Plano Piloto foi definido por um sistema de pontos que privilegiava funcionários escolhidos segundo os critérios de mais longo período trabalhado, maiores ganhos salariais, maior número de dependentes e função exercida (Bertone, 1987). Do ponto de vista das funções urbanas, um primeiro diagnóstico mais detido, realizado no início dos anos 1970, constatou que as cidades-satélites possuíam então $70 \%$ da população do Distrito Federal e apresentavam alto grau de dependência em relação ao Plano Piloto no que diz respeito a empregos, serviços e comércio, implicando grande volume de deslocamentos diários àquele centro (Paviani e Ferreira, 1974).

Os planos urbanísticos realizados entre os anos 1960 e 1970 contribuíram para o estabelecimento de um padrão de cidade-satélite como subúrbio-dormitório, de modo contrário ao ideário da descentralização planejada. Os traçados são via de regra caracterizados por superquadras com longas sequências contínuas de lotes para casas unifamiliares e apresentam frequentes espaços livres de caráter residual, por vezes decorrentes de acréscimos posteriores de novos setores habitacionais. 0 conceito de unidade de vizinhança está presente nesses traçados, mas os equipamentos urbanos nem sempre viriam a ser construídos ou demorariam a sê-lo. A disparidade na distribuição de serviços de infraestrutura no núcleo central e nas cidades-satélites foi marcante: estima-se que, até meados da década de 1970, redes de esgoto em larga escala só existiam no Plano Piloto e seu entorno imediato (Brito, 2009). Há uma considerável desigualdade socioeconômica entre o Plano Piloto e as regiões administrativas (antes denominadas cidades-satélites), o que também está visível na qualidade e na quantidade da infraestrutura existente no território (Carli e Bertussi, 2018). 


\section{Considerações finais: as peculiares cidades-satélites brasilienses}

Arquitetos e autoridades da Novacap, cientes das formulações de um ideário europeu em planejamento, viram as cidades-satélites de Brasília como um desvirtuamento: conforme mencionado, Lúcio Costa (1974b) aludiu a "pseudocidades-satélites" e Ernesto Silva (1987) assegurou que Taguatinga não poderia ser considerada uma cidade-satélite, pois "não tem vida própria". Se tomarmos as propostas elaboradas para Londres na primeira metade do século 20 como referência modelar, podemos mesmo dar razão a eles. No entanto, também se pode ver que, em textos administrativos e na vivência cotidiana da cidade, estabeleceu-se uma noção de cidade-satélite peculiar a Brasília. A denominação havia sido oficializada em decreto presidencial de 1960, onde se lê que caberia ao DF "zelar pela cidade de Brasília, pelas cidades-satélites e comunidades que a envolvem" (lei n. 3.751, de 13 de abril de 1960), desse modo sugerindo que Brasília corresponderia ao Plano Piloto e não abarcaria os demais núcleos do território. Mas, já em 1964, o Plano Piloto e as cidades-satélites receberam a denominação uniformizada de regiões administrativas, distinguindo-se pela numeração atribuída a cada uma delas. As regiões administrativas impuseram-se como principal circunscrição territorial interna ao DF e foram sendo continuamente redivididas, numa tentativa de acompanhar seu intenso processo de urbanização. ${ }^{2}$

No entanto, ainda em 1998 um decreto proibiu, em documentos oficiais, "a utilização da expressão 'satélite' para designar as cidades situadas no território do Distrito Federal", considerando que "as aglomerações urbanas do Distrito Federal já assumem características de cidades, cada vez mais independentes social, econômica e culturalmente do Plano Piloto" (Decreto n. 19.040, de 18 de fevereiro de 1998). O decreto refere-se a cidades, quando a denominação oficial correta seria regiões administrativas. De todo modo, o uso ainda corrente da expressão cidade-satélite revela o impacto a longo prazo dos discursos políticos veiculados na época da construção de Brasília, quando aqueles núcleos periféricos foram assim denominados. 0 decreto de 1998 parece ter sido motivado pela intenção de reconhecer os núcleos periféricos como entidades urbanas de fato independentes. Cabe notar, porém, que, como vimos na análise de propostas de descentralização planejada na Inglaterra na primeira metade do século 20 , o caráter relativamente independente é considerado essencial para a definição de cidades-satélites; já, no decreto em questão, é o que justifica, ao contrário, que essa designação de satélite seja banida - embora sua autonomia seja ainda muito questionável. 0 texto do decreto cita várias melhorias que teriam sido feitas na infraestrutura urbana e nos sistemas de saúde e educação, de modo a veicular certa imagem daqueles núcleos associada à atuação do governo do DF. A motivação subjacente ao decreto deve ter sido, enfim, a tentativa de banir uma expressão que havia adquirido forte conotação negativa e se tornara reveladora de um contexto de desigualdade socioespacial.

Das propostas para a metrópole londrina à criação de uma capital no interior do Brasil, a trajetória das "cidades-satélites" evidencia os significados fluidos e contraditórios que os conceitos urbanísticos podem assumir 
em suas reinterpretações. De modo muito distinto daquilo que preconizara um ideário inglês de planejamento urbano e regional e como resultado da assimilação de alguns seus princípios a um processo específico -, as cidades-satélites de Brasília foram essenciais para definir uma peculiar configuração metropolitana. Brasília tornou-se a terceira metrópole nacional, considerando a rede urbana sob sua região de influência, e a quarta metrópole nacional em extensão de área urbanizada (Codeplan, 2018). Considerar a intrínseca participação das cidades-satélites na concepção de Brasília contribui para revelar as peculiaridades da formação da capital e traz a necessidade de rever formulações usuais numa historiografia que privilegiou o projeto do Plano Piloto. Além disso, vale lembrar que argumentos de fundo histórico sobre Brasília permanecem sendo evocados em discussões, da maior atualidade, acerca do seu patrimônio cultural e da gestão metropolitana.

\section{[I] http://orcid.org/0000-0001-8083-1274}

Universidade de Brasília, Faculdade de Arquitetura e Urbanismo, Programa de Pós-Graduação em História. Brasília, DF/Brasil.

fernandafau@unb.br

\section{Agradecimento}

Este trabalho contou com apoio do CNPq (Conselho Nacional de Desenvolvimento Científico e Tecnológico - Brasil), processo n. 452015/2018-9.

\section{Notas}

(1) Cabe notar que esse dado foi superestimado, pois, dez anos após a inauguração de Brasília, a população do Plano Piloto era de 236.777 habitantes, e o DF tinha 538.351 habitantes (IBGE, 1971).

(2) O Distrito Federal foi subdividido em sete subprefeituras em 1961, oito regiões administrativas (RAs) em 1964, 12 RAs em 1964 e 12 RAs em 1990. Em 2008, havia 21 RAs e, desde 2011, há 31 delas. 


\section{Referências}

ABERCROMBIE, P. (1945). Greater London Plan 1944. London, His Majesty's Stationery office.

ALBUQUERQUE, L. (1960). Introdução ao urbanismo regional: sistema de abastecimento de Brasília. Rio de Janeiro, Conselho Coordenador do Abastecimento da Novacap.

ANGOTTI-SALGUEIRO, H. e SIMÕES JR, J. G. (2017). Por uma reflexão sobre Pioneiros do Urbanismo no Brasil e modalidades de apropriação de ideários internacionais - revisando terminologias e conceitos. Arquitextos. São Paulo, ano 17, n. 203.01, Vitruvius. Disponível em: http://www. vitruvius.com.br/revistas/read/arquitextos/17.203/6516. Acesso em: 5 maio 2017.

BELOTO, G. E. (2015). Da região à metrópole: o território desenhado pelos modelos conceituais. Tese de Doutorado. São Paulo, Universidade de São Paulo.

BERTONE, L. F. (1987). “O Estado e a urbanização do Distrito Federal”. In: PAVIANI, A. (org.). Urbanização e metropolização: a gestão dos conflitos em Brasília. Brasília, EdUnB/Codeplan, pp. 51-72.

brasília: revista da Companhia Urbanizadora da Nova Capital do Brasil (1957, 1958, 1959, 1960). Rio de Janeiro, NOVACAP, ano 1, n. 11, nov. 1957; ano 2, n. 15, mar. 1958, jan. 1959; ano 4, n. 44, ago. 1960 .

BRITO, J. D. de (2009). De Plano Piloto a metrópole: a mancha urbana de Brasília. Tese de Doutorado. Brasília, Universidade de Brasília.

BRUAND, Y. (2003). Arquitetura contemporânea no Brasil. São Paulo, Perspectiva.

CARVER, H. (1962). Cities in the suburbs. Toronto, University of Toronto Press.

CARLI, P. B. de e BERTUSSI, G. L. (2018). Análise da infraestrutura das regiões administrativas do Distrito Federal. Texto para discussão, n. 41. Brasília, Codeplan, maio 2018. Disponível em: http://www. codeplan.df.gov.br/wp-content/uploads/2018/02/TD-41-An\%C3\%A1lise-da-Infraestrutura-dasRegi\%C3\%B5es-Administrativas-do-Distrito-Federal.pdf. Acesso em: 6 dez 2018.

CHERRY, G. E. e PENNY, L. (1986). Holford. A study in architecture, planning and civic design. Londres e Nova York, Alexandrine Press.

COSTA, L. (1991[1957]). “Relatório do Plano Piloto de Brasília”. In: Relatório do Plano Piloto de Brasília. Brasília, GDF.

(1974a). “Considerações em torno do Plano-Piloto de Brasília”. In: SENADO FEDERAL. I Seminário de Estudos dos Problemas de Brasília. Brasília, Senado Federal, pp. 21-29.

(1974b). “Primeira carta dirigida ao Senador Catete Pinheiro..." In: SENADO FEDERAL. I Seminário de Estudos dos Problemas de Brasília. Brasília, Senado Federal, pp. 289-292.

(2012). "'Ingredientes' da concepção urbanística de Brasília". In: XAVIER, A. e KATINSKY, J. R. (org.) (2012). Brasília, antologia crítica. São Paulo, Cosac Naify.

DERNTL, M. F. (2018). Além do Plano. A concepção das cidades-satélites de Brasília. Arquitextos. São Paulo, ano 19, n. 221.03, Vitruvius. Disponível em:http://www.vitruvius.com.br/revistas/read/ arquitextos/19.221/7150. Acesso em: 3 maio 2019.

EPSTEIN, D. (1973). Brasilia, Plan and Reality: a study of planned and spontaneous developments. Berkeley, University of California. 
EVENSON, N. (1973). Two Brazilian capitals: architecture and urbanism in Rio de Janeiro and Brasília. Londres, Yale University Press.

FELDMAN, S. (2009). 1950. A década de crença no planejamento regional no Brasil. In: XIII ENCONTRO NACIONAL DA ANPUR. Florianópolis, UFSC, v. 1, pp. 1-23.

(2014). Entre o regional e o metropolitano: pensamento urbanístico e metrópole no Brasil na década de 1950. Revista USP, pp. 13-22.

FICHER, S. (2019). Das imprevidentes baixas densidades à imprudente verticalização. Urbana - Revista eletrônica do Centro Interdisciplinar de Estudos da Cidade, v. 10, pp. 278-298.

FICHER, S. e PALAZZO, P. P. (2005). Paradigmas urbanísticos de Brasília. Cadernos PPG-AU/FAUFBA. Salvador, v. Ed esp, pp. 49-71.

GASKELL, S. M. (1981). “'The suburb salubrious': town planning in practice”. In: SUTCLIFFE, A. (ed.). British Town Planning: The Formative Years. Leicester, Leicester University Press.

HALL, P. (2011). Cidades do amanhã. São Paulo, Perspectiva.

HALL, P. et al. (eds.) (1973). The Containment of Urban England. London, George Allen \& Unwin.

HARDY, D. (1991). From garden cities to new towns: campaigning for town and country planning, 1899-1946. Nova York, Routledge, Chapman \& Hall.

HILBERSEIMER, L. (2012). Metropolisarchitecture and selected essays. Nova York, GSAPP Sourcebook.

HOLANDA, F. de; RIBEIRO, R. e TENORIO, G. (2015). Brasilia: transformações na ordem urbana. Rio de Janeiro, Letra Capital.

HOLFORD, W. (2012[1957]). "Reflexões sobre o Concurso [19 mar. 1957]". In: XAVIER, A. e KATINSKY, J. R. (orgs.). Brasília: Antologia Crítica. São Paulo, Cosac Naify.

HOLFORD, W. et al. (1991[1957]). “Apreciação do Júri sobre o projeto de Lucio Costa”. In: RELATÓRIO do Plano Piloto de Brasília. Brasília, GDF, pp. 46-47.

HOLSTON, J. (1993). A Cidade Modernista: uma crítica de Brasília e sua utopia. São Paulo, Companhia das Letras.

HOWARD, E. (1902). Garden cities of tomorrow. Londres, S. Sonnenschein.

IBGE (1971). Sinopse Preliminar do Censo Demográfico, VIII Recenseamento Geral -1970. Rio de Janeiro, IBGE. Disponível em: https://biblioteca.ibge.gov.br/visualizacao/periodicos/311/cd_1970_ sinopse_preliminar_df.pdf. Acesso em: 14 jun 2019.

KOHLSDORF, M. E (1985). “As Imagens de Brasília”. In: PAVIANI, A. (org.). Brasília, ideologia e realidade: o espaço urbano em questão. Sao Paulo, Projeto, pp. 161-190.

(1996). “Brasília, mosaico morfológico". In: SEMINÁRIO SOBRE HISTÓRIA DA CIDADE E DO URBANISMO. Anais... Rio de Janeiro, Prourb/FAU/UFRJ, pp. 680-687.

KOHLSDORF, M. E. ; KOHLSDORF, G. e HOLANDA, F. R. B. (2013). "Brasília: permanência e metamorfoses”. In: DEL RIO, V. e SIEMBIEDA, W. (orgs.). Desenho urbano contemporâneo no Brasil. Rio de Janeiro, LTC, v. 1, pp. 39-55.

LETHABY, W. R et al. (1921).Town Theory and Practice. Londres, Benn Bros.

LUCCHESE, M. C. (2009). Em defesa do planejamento urbano: ressonâncias britânicas e a trajetória de Harry James Cole. Tese de doutorado. São Carlos, Universidade de São Paulo. 
NOVICK, A. (2010). “Intercambios Internacionales en construcción de la ciudad. Apuntes para un estado del Arte". In: SALGADO, I. e BERTONI, A. (orgs.). Da construção do território ao planejamento das cidades. São Carlos, RiMa, pp. 81-90.

OLIVEIRA, G. O. de (2005). Lucio Costa. Entrevista, São Paulo, ano 6, n. 023.03, Vitruvius, Disponível em: http://www.vitruvius.com.br/revistas/read/entrevista/06.023/3313. Acesso em: 18 fev 2016.

OSBORN, F. (1969). Green-belt cities. New ed. with a forward by Lewis Mumford. Londres, Evelyn, Adams \& Mackay.

PAVIANI, A. (1985). “A metrópole terciária". In: PAVIANI, A. (org.). Brasília, ideologia e realidade: o espaço urbano em questão. São Paulo, Projeto, pp. 57-79.

PAVIANI, A. e FERREIRA, I. C. B. (1974). “As correntes migratórias para o Distrito Federal: aspectos sócio-econômicos”. In: SENADO FEDERAL. I Seminário de Estudos dos Problemas de Brasília. Brasília, Senado Federal, pp. 239-241.

PURDOM, C. B (1949). The Building of Satellite Towns. Londres, J. M. Dent \& Sons.

RABELO JR., M. (1992). Os núcleos rurais do Distrito Federal. Dissertação de Mestrado. Campina Grande, Universidade Federal da Paraíba.

REGO, R. L. (2015). A integração cidade-campo como esquema de colonização e criação de cidades novas: do Norte Paranaense à Amazônia Legal. Revista Brasileira de Estudos Urbanos e Regionais, [S.I.], v. 17, n. 1. Disponível em: http://rbeur.anpur.org.br/rbeur/article/view/4978. Acesso em: 14 jun 2019

SENADO FEDERAL (1974). I Seminário de Estudos dos Problemas de Brasília. Brasília, Senado Federal.

SEVERO, C. S. (1974). "Plano-Diretor de transportes urbanos". In: SENADO FEDERAL. I Seminário de Estudos dos Problemas de Brasília. Brasília, Senado Federal.

SICA, P. (1981). Historia de Urbanismo. El siglo XX. Madrid, Instituto de Estudios de Administración Local.

SILVA, E. (1970). História de Brasília: um sonho, uma esperança, uma realidade. Brasília, Coordenada. (1987). Ernesto Silva: depoimento [ago. 1987]. Entrevistadores: M. Santos, M. Ramos e T. Sousa. Brasília, Arquivo Público do Distrito Federal, 21 pgs. Entrevista concedida ao Programa de História Oral do Arquivo Público do Distrito Federal.

TAVARES, J. (2004). Projetos para Brasília e a cultura urbanística nacional. Dissertação de Mestrado. São Carlos, Universidade de São Paulo.

THOMAS, D. (1964). London's Green Belt: the evolution of an idea. Ekistics, v. 17, n. 100, pp. 177-181. Disponível em: www.jstor.org/stable/43616123. Acesso em: 8 jan 2018.

TURKIENICZ, B. (1987). “A morfologia das cidades-satélites de Brasília”. In: PAVIANI, A. (org.). Urbanização e metropolização: a gestão dos conflitos em Brasília. Brasília, EdUnB, pp. 181-186. 